\title{
Article \\ Allelopathic Potential of Haloxylon persicum against Wheat and Black Mustard with Special Reference to Its Phytochemical Composition and Antioxidant Activity
}

\author{
Ibrahim Bayoumi Abdel-Farid ${ }^{1,2}, *$, Mohamed Salah Massoud ${ }^{3}$, Yahia Al-Enazy ${ }^{1}$, \\ Arafat Abdel Hamed Abdel Latef ${ }^{4}{ }^{\mathbb{D}}$, Muhammad Jahangir ${ }^{5}$ and Nasr H. Gomaa ${ }^{6}$
}

check for updates

Citation: Abdel-Farid, I.B.; Massoud, M.S.; Al-Enazy, Y.; Abdel Latef, A.A.H.; Jahangir, M.; Gomaa, N.H. Allelopathic Potential of Haloxylon persicum against Wheat and Black Mustard with Special Reference to Its Phytochemical Composition and Antioxidant Activity. Agronomy 2021, 11, 244. https://doi.org/10.3390/ agronomy11020244

Academic Editors: Natividad Chaves Lobón, Juan Carlos Alías Gallego and Sara Rodrigo

Received: 31 December 2020

Accepted: 26 January 2021

Published: 28 January 2021

Publisher's Note: MDPI stays neutra with regard to jurisdictional claims in published maps and institutional affiliations.

Copyright: (c) 2021 by the authors. Licensee MDPI, Basel, Switzerland. This article is an open access article distributed under the terms and conditions of the Creative Commons Attribution (CC BY) license (https:// creativecommons.org/licenses/by/ $4.0 /)$.
1 Department of Biology, College of Science, Jouf University, Sakaka P.O. Box 2014, Saudi Arabia; alenazyyahia@gmail.com

2 Department of Botany, Faculty of Science, Aswan University, Aswan 81528, Egypt

3 Chemistry Department, College of Science and Arts, Jouf University, Al-Qurayyat 75911, Saudi Arabia; massoud_ms65@sci.aswu.edu.eg

4 Department of Biology, Turabah University College, Turabah Branch, Taif University, P.O. Box 11099, Taif 21944, Saudi Arabia; a.moawd@tu.edu.sa

5 Department of Food Science \& Technology, The University of Haripur, Haripur 22620, Pakistan; m.jahangir@uoh.edu.pk

6 Department of Botany and Microbiology, Faculty of Science, Beni-Suef University, Beni-Suef 62521, Egypt; nasr.gomaa@science.bsu.edu.eg

* Correspondence: bayoumi2013@aswu.edu.eg; Tel.: +966-535040657

Abstract: Haloxylon persicum is a well-known plant of sandy deserts, but yet, its allelopathic and phytochemical potential has not been explored. In the present study, we evaluated the effects of different concentrations $(1 \%, 2 \%, 4 \%$, and $8 \%$ ) of the aqueous extract of $H$. persicum shoots on seed germination and seedling growth of wheat crop and black mustard weed. The effects of the same extract on the biochemical parameters (chlorophyll a, chlorophyll b, carbohydrates content, and proline content) of wheat seedlings were also investigated. Low and moderate concentrations $(1 \%, 2 \%$, and $4 \%)$ of $H$. persicum aqueous extract nonsignificantly affected seed germination, shoot length, root length, fresh weight, and dry weight of wheat seedlings, whereas these parameters were negatively affected by the application of the highest extract concentration $(8 \%)$. The results revealed a significant increase in proline content in wheat seedlings under all the applied concentrations of $H$. persicum extract. Low and moderate concentrations (1-4\%) of $H$. persicum extract significantly enhanced chlorophyll $\mathrm{a}$, chlorophyll $\mathrm{b}$, and total chlorophyll content in wheat seedlings, whereas these parameters were significantly reduced when the highest extract concentration (8\%) was applied. Only the lowest concentration (1\%) of $\mathrm{H}$. persicum extract reduced the carbohydrates content of wheat seedlings, while other concentrations showed nonsignificant effects. Concentrations of $4 \%$ and $8 \%$ of H. persicum extract reduced the seed germination percentage of black mustard. The root length, shoot length, and fresh weight of black mustard seedlings were significantly decreased by the application of $1 \%$ and $2 \%$ extract concentrations and completely inhibited in response to treatment with $4 \%$ and $8 \%$ concentrations. The dry weight of black mustard seedlings was not affected by $1 \%$ and $2 \%$ extract concentrations but completely inhibited at $4 \%$ and $8 \%$ concentrations. The methanol extract of H. persicum contains high contents of bioactive secondary metabolites, such as phenolics, flavonoids, flavonols, anthocyanins, tannins, saponins, as well as proved to has a very strong antioxidant activity of the 2,2-diphenyl-1-picrylhydrazyl radical scavenging activity (DPPH). Based on our results, we recommend the potential application of the aqueous extracts of $H$. persicum to control black mustard weed in wheat crops. Furthermore, $H$. persicum revealed an interesting phytochemical pattern with sound antioxidant activity that assigns this plant as a promising candidate to explore its detailed metabolomics profile along with potential bioactivities.

Keywords: allelochemicals; chlorophyll; DPPH; germination; Haloxylon persicum; PCA; proline; carbohydrates; seedling growth 


\section{Introduction}

One of the major challenges to wheat growth and yield is its interspecific competition with weeds, such as black mustard (Brassica nigra (L.) Koch), for environmental resources [1-4]. The application of weedicides is considered as one of the suitable practices to control weeds' growth, but unfortunately, it comes with major concerns about food safety as well as causing environmental pollution $[5,6]$. It leads the interest of the scientific community to search for natural measures for growth inhibition of these noxious weed species [7-9]. Interestingly plants represent a rich source of biologically active molecules with species-specific allelopathic potential by supporting the growth of some species and retarding the growth of others at the same time [10-12]. These phytochemicals belong to diverse groups, including phenols, alkaloids and terpenes [13], saponins [14,15], glucosinolates and their enzymatic degradation products (isothiocyanates) [16], with varying concentrations in different plant species [17].

These metabolites affect some plant species by altering the plant's biological fluxes, affecting photosynthetic pigments [18,19], which leads to the inhibition of seed germination, and root and shoot growth [14]. Most of these allelochemicals are soluble in water and are found in all plant parts, such as root, stem, rhizome, leaves, flowers, fruits, and seeds [13-16], and so can be used in foliar as well as soil applications for their desired positive or negative effects on seeds, seedlings, or adult plants $[20,21]$.

Although there is a number of plants that have been reported for potential weed control in economically important crops [22-24], a lot needs to be done to find high efficiency and more targeted weed control allelopathic plants [22,23,25-30]. Deserts have a vast resource of native plants rich in bioactive metabolites (e.g., alkaloids, saponins, tannins, flavonoids, anthocyanins, and phenols), produced by plants under an extremely harsh environment [31,32].

Haloxylon persicum Bunge ex Boiss and Buhse (locally known as Al-Ghada) is a wellknown desert plant used in rehabilitating pastures, afforesting desert roads, furniture, paper, and dyes manufacturing [33]. The geographical distribution of H. persicum extends to cover several countries, including Central Asia, West Asia, the Arabian Peninsula, Iran, Russia, China, Sinai desert, and many other countries [33-36].

The present study aimed to evaluate the allelopathic effects of the aqueous extract of H. persicum on wheat crops and black mustard weed. Furthermore, the phytochemical diversity along with the antioxidant potential of $H$. persicum was also investigated.

\section{Materials and Methods}

\subsection{Samples Collection}

The young vegetative shoots of H. persicum were collected in January 2019 from the Sakaka area in the Al-Jouf region (northern west of KSA) and were dried in the dark in the laboratory at ambient temperature for 15 days. The air-dried shoots were ground using an electric mixer into a fine powder. Wheat grains (Triticum aestivum L.), variety Sindhi, were obtained from a farmer in the Omlej area in KSA, and black mustard seeds (Brassica nigra) were collected from wheat fields in Egypt.

\subsection{Extraction and Preparation of H. persicum Aqueous Extract}

The stock (20\%) aqueous extract solution of H. persicum was prepared from the shoots by soaking $100 \mathrm{~g}$ of powdered materials in $500 \mathrm{~mL}$ of sterilized distilled water for $24 \mathrm{~h}$ at ambient temperature. Then, the solution was filtered through Whatman filter paper. Serial dilutions $(1 \%, 2 \%, 4 \%$, and $8 \%)$ from stock were prepared in sterilized distilled water. Three replicates were used in all experiments for each treatment.

\subsection{In Vitro Germination Experiment}

Homogenized size wheat grains and black mustard seeds were soaked for $30 \mathrm{~min}$ in distilled water. Surface sterilization was done by soaking seeds in $70 \%$ ethanol for $30 \mathrm{~s}$, then washing 4 times in sterilized distilled water after soaking for $10 \mathrm{~min}$ in $5 \%$ 
sodium hypochlorite. Afterward, 10 seeds were transferred into $10 \mathrm{~cm}$ sterile Petri dishes containing filter papers. Five groups of Petri dishes were prepared: The first group received only sterilized distilled water (control), the second group received $1 \% \mathrm{H}$. persicum aqueous extract, the third group received $2 \%$, the fourth group received $4 \%$, and the fifth group received $8 \%$ of $H$. persicum aqueous extract. The germinated seeds were counted as the radicle was seen to the naked eye after its emergence from the testa $[37,38]$. Seed germination percentages were daily recorded and used to evaluate the germination rate of wheat and black mustard. On the ninth day of the experiment, the germination percentage for each treatment was calculated.

Based on nine randomly selected seedlings from all replicates of each treatment, the root and shoot lengths were measured by a ruler [39]. Directly after harvesting, the fresh weights were determined, and after removal of water content and drying in the oven at $105^{\circ} \mathrm{C}$ for $24 \mathrm{~h}$, the dry weights were calculated.

\subsection{Biochemical Characteristics of Wheat Seedlings}

A spectrophotometer (PD-303 UV, APEL CO., Ltd., Japan) was used for the determination of carbohydrates, proline, and photosynthetic pigments contents in wheat, as well as for the determination of secondary metabolites and 2,2-diphenyl-1-picrylhydrazyl (DPPH) radical scavenging activity of $H$. persicum. More details considering the determination of these metabolites are found in a previous report [40].

\subsubsection{Determination of Carbohydrates}

Dried samples were used to determine carbohydrates by using anthrone reagent [41]. The concentrations of carbohydrates in plant samples were calculated and expressed as $\mathrm{mg} \mathrm{g}^{-1}$ dry weight (DW).

\subsubsection{Determination of Free Proline}

Fresh samples were used to determine proline contents as $\mathrm{mg} \mathrm{g}^{-1}$ of fresh weight (FW) using an acidic ninhydrin reagent [42].

\subsubsection{Determination of Photosynthetic Pigments}

Fresh samples were used to quantify the photosynthetic pigments (chlorophyll a, chlorophyll $b$, and total chlorophyll) following a previously reported method [43]. Fresh plant samples $(50 \mathrm{mg})$, were extracted in absolute methanol, vortexed, then homogenized, and centrifuged for $10 \mathrm{~min}$ at $1000 \mathrm{rpm}$. The supernatant was separated, and its absorbance was determined at $666 \mathrm{~nm}$ and $653 \mathrm{~nm}$. Chlorophyll a and chlorophyll b contents were calculated. The pigment content was reported as $\mu \mathrm{g} \mathrm{g}^{-1} \mathrm{FW}$ was based on the following equations [43]:

$$
\begin{aligned}
& \text { Chlorophyll a }=15.65 \text { A666 - 7.34 A653 } \\
& \text { Chlorophyll b }=27.05 \text { A653 - 11.21 A666 }
\end{aligned}
$$

\subsection{Phytochemical Analysis of H. persicum Shoots for Secondary Metabolites}

\subsubsection{Plant Extraction}

The powdered shoots of $H$. persicum were immersed in $80 \%$ methanol for $24 \mathrm{~h}$, and this mixture was filtrated through Whatman filter paper. The filtrate was evaporated under low pressure by a rotary evaporator, and the resulting crude methanol extract was used for evaluating the phytochemical analysis and antioxidant activity of H. persicum.

\subsubsection{Determination of Total Phenolics (TP)}

The plant extract or different dilutions of gallic acid (as standard) were mixed with Folin Ciocalteau reagent to determine total phenolics as $\mathrm{mg} \mathrm{g}^{-1}$ gallic acid equivalent. One $\mathrm{mL}$ of $10 \% \mathrm{Na}_{2} \mathrm{CO}_{3}$ solution was added and mixed. The mixture was allowed to stand for $1 \mathrm{~h}$ at room temperature, and the absorbance was measured at $700 \mathrm{~nm}$ [44]. 


\subsubsection{Determination of Total Flavonoids (TF)}

Total flavonoids ( $\mathrm{mg} \mathrm{g}^{-1}$ quercetin equivalent) were determined according to a previously reported method [45]. The plant extract (samples) and different dilutions of quercetin for constructing the standard curve were mixed with $5 \% \mathrm{NaNO}_{2}$ solution in water. Six min later, $10 \%(w / v) \mathrm{AlCl}_{3}$ solution in water was added, and the mixture was allowed to stand for a further $6 \mathrm{~min}$, then $1 \mathrm{M} \mathrm{NaOH}$ was added. The mixture was vortexed well and rested for $12 \mathrm{~min}$, and the absorbance was read at $510 \mathrm{~nm}$.

\subsubsection{Determination of Total Flavonols}

The content of flavonols was determined ( $\mathrm{mg} \mathrm{g}^{-1}$ of quercetin equivalent) through a previously reported method [46]. The methanol plant extract was mixed with $0.2 \%$ aluminum chloride and $5 \%$ sodium acetate. A series of quercetin dilutions were treated as the samples to construct a standard curve for control. After $2.5 \mathrm{~h}$, the absorbance of both standard and samples was read at $440 \mathrm{~nm}$.

\subsubsection{Determination of Total Anthocyanins}

Plant samples were dissolved in acidified methanol in brown tubes or well-closed tubes covered with aluminum foils and incubated at $+4{ }^{\circ} \mathrm{C}$ for $24 \mathrm{~h}$ [47]. The absorbance of the supernatants after centrifugation was recorded at $530 \mathrm{~nm}$ and $657 \mathrm{~nm}$. The anthocyanins content was calculated using the following equation as $\mu$ mole $\mathrm{g}^{-1}$ :

$$
\text { Anthocyanin }\left(\mu \text { mole g }^{-1}\right)=\left[\frac{\mathrm{A} 530-0.33 \times \mathrm{A} 657}{31.6}\right] \times \frac{\text { Volume }(\mathrm{mL})}{\text { Weight }(\mathrm{g})}
$$

\subsubsection{Determination of Total Condensed Tannins}

Total condensed tannins (as mg catechol equivalent $\mathrm{g}^{-1}$ ) were measured using the vanillin assay as previously reported by Julkunen-Titto [48]. Vanillin/methanol solution $(w / v)$ was added to a methanol plant extract, and the solution was vortexed. Concentrated hydrochloric acid was added to the mixture and allowed to react at room temperature for $20 \mathrm{~min}$. A series of catechol dilutions as a standard were treated as mentioned before, and the standard curve was developed. The absorbance of samples and standard was recorded at $550 \mathrm{~nm}$.

\subsubsection{Determination of Total Saponins}

The saponin content ( $\mathrm{mg} \mathrm{g}^{-1}$ saponin equivalent) was determined using vanillin reagent at $473 \mathrm{~nm}$, according to Ebrahimzadeh and Niknam [49].

\subsubsection{Determination of 2,2-Diphenyl-1-Picrylhydrazyl (DPPH) Free Radical} Scavenging Activity

Different concentrations of crude extracts and ascorbic acid as a standard were used to evaluate the DPPH radical scavenging activity using a spectrophotometer in the presence of $0.5 \mathrm{M}$ acetic acid buffer solution at $\mathrm{pH} 5.5$ and $0.2 \mathrm{mM}$ and 50\% DPPH in ethanol [50]. After the incubation of the solutions at ambient temperature for $30 \mathrm{~min}$, the remaining amount of DPPH was determined by reading the absorbance at $517 \mathrm{~nm}$. The antiradical effect of the plant extract was compared with ascorbic acid as a positive control.

$$
\% \text { DPPH radical scavenging activity }=\mathrm{Ac}-\left[\frac{\mathrm{As}}{\mathrm{Ac}}\right] \times 100
$$

where $A c=$ Absorbance of negative control at $517 \mathrm{~nm}$; As = Absorbance of the sample at $517 \mathrm{~nm}[51]$.

The $\%$ inhibitions were plotted against concentrations, and $\mathrm{IC}_{50}$ was calculated from the graph. 


\subsection{Statistical Analysis}

The level of significances for the germination percentage, shoot length, root length, fresh and dry weights of seedlings, the content of proline, the content of carbohydrates, and the contents of photosynthetic pigments between control and treated plants was evaluated by the one-way analysis of variance (ANOVA) using Minitab ver. 12.21. Data are a mean with a standard deviation of three replicates. $p$-Values $<0.05,<0.01$ and $<0.001$ were considered significant, highly significant, and very highly significant, respectively. To evaluate the effect of allelopathic stress of $H$. persicum aqueous extract on seed germination and seedling growth of black musard and on seed germination, seedling growth, and biochemical features of wheat, principal component analysis (PCA) was performed with SIMCA-P software (ver. 14.1, Umetrics, Umeå, Sweden) to reduce the dimensionality among these data sets.

\section{Results and Discussion}

3.1. Effect of H. persicum Aqueous Extract on Seed Germination and Seedling Growth of Wheat and Black Mustard

The concentrations of 2-8\% of the aqueous extract of $H$. persicum significantly reduced the germination rate in black mustard, whereas the germination rate of wheat was only significantly reduced due to treatment with the highest concentration of H. persicum extract $(8 \%)$ (Figure 1A,B). On the last day of the experiment, $4-8 \%$ extract concentrations significantly reduced the germination percentage in black mustard seeds $(p<0.05)$, whereas this trend was observed in wheat only under the highest concentration (8\%) (Figure 2).

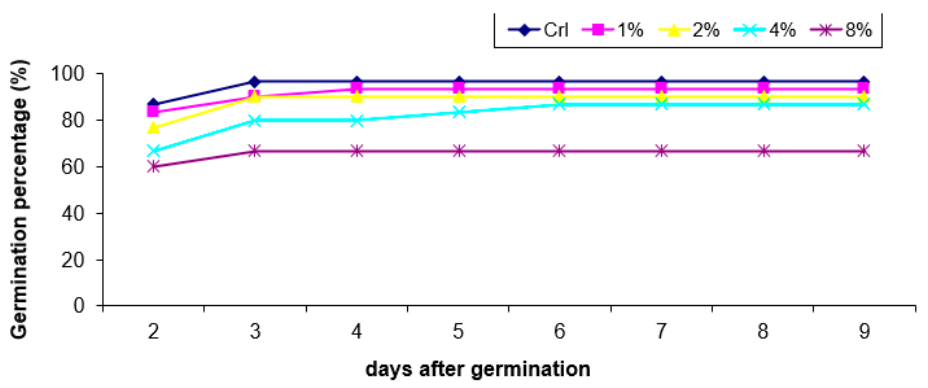

(A)

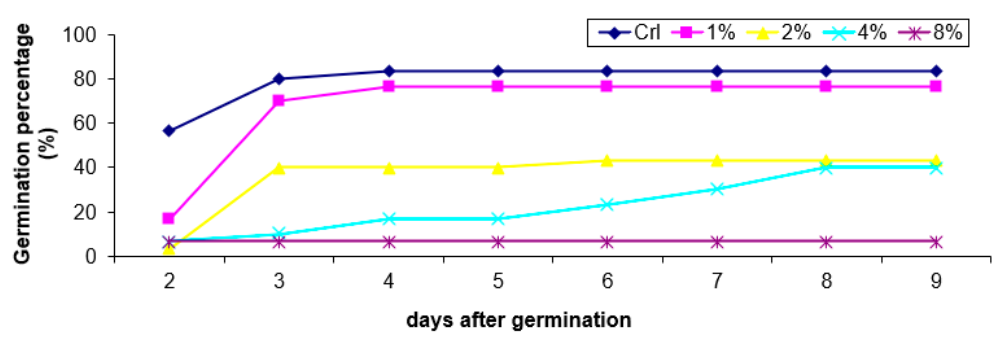

(B)

Figure 1. Effect of the aqueous extract of $H$. persicum on the germination rate of wheat (A) and black mustard (B). 


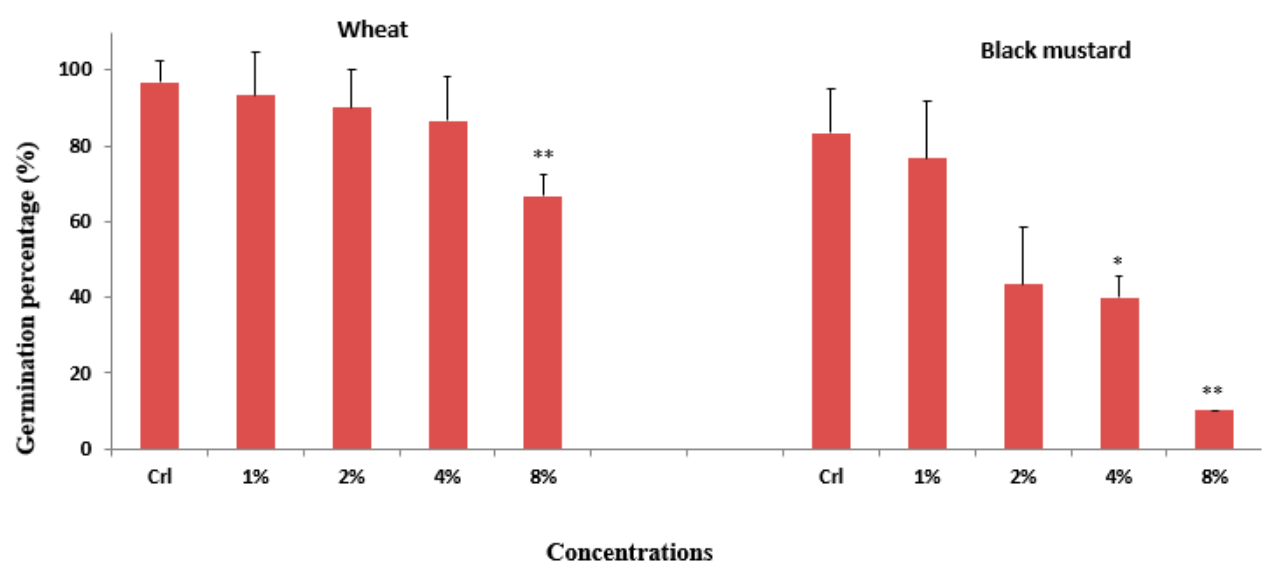

Figure 2. Effect of the aqueous extract of $H$. persicum on seed germination in wheat and black mustard determined on the ninth day of the experiment. ${ }^{*}=$ significant and ${ }^{* *}=$ highly significant. $\mathrm{Crl}=\mathrm{Control}$, No stars on the bars means there is no significant change.

The low and moderate concentrations of $H$. persicum (1-4\%) had no effect, but the highest concentration ( $8 \%$ ) had a significant inhibitory effect on wheat shoot length (Figure 3A). On the other hand, application of $1 \%$ and $2 \%$ extract concentrations of $H$. persicum significantly reduced the shoot length of black mustard (2.1 and $0.8 \mathrm{~cm}$, respectively) compared to control $(3.1 \mathrm{~cm})$, while treatment with $4 \%$ and $8 \%$ concentrations completely inhibited shoot growth (Figure 3A). The strong suppressive effect of the extract on the shoot length of the black mustard plant was concentration-dependent (Figure 3A).

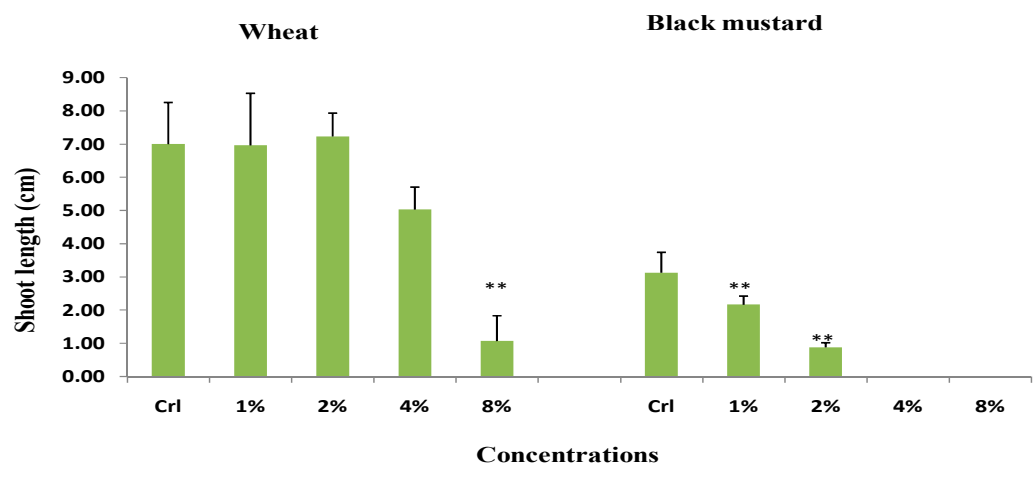

(A)

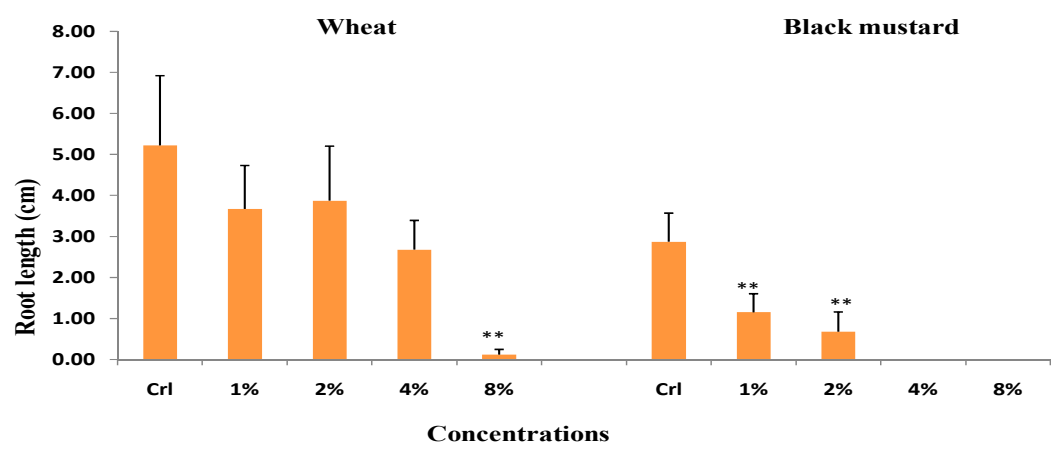

(B)

Figure 3. Effect of the aqueous extract of $H$. persicum on shoot length $(\mathbf{A})$ and root length $(\mathbf{B})$ of wheat and black mustard seedlings. ${ }^{* *}=$ highly significant, $\mathrm{Crl}=\mathrm{Control}$.

Both wheat and black mustard showed different levels of responses of root length to the allelochemical stress. The effect of $H$. persicum aqueous extract on root length 
was similar to its effect on shoot length, whereas only the highest concentration (8\%) significantly reduced the root length in wheat. In the case of black mustard seedlings, the root length was significantly reduced at $1 \%$ and $2 \%$ concentrations and completely inhibited due to treatment with $4 \%$ and $8 \%$ concentrations (Figure 3B).

For wheat, neither low nor moderate concentration (1-4\%) of $H$. persicum extract significantly affected the fresh and dry weights of seedlings (Figure 4A,B). The fresh weight of black mustard seedlings was significantly reduced by $1 \%$ and $2 \%$ concentrations and completely inhibited by $4 \%$ and $8 \%$ concentrations of $H$. persicum extract. The dry weight of black mustard seedlings was inhibited in response to treatment with $4 \%$ and $8 \%$ concentrations of $H$. persicum extract (Figure $4 \mathrm{~A}, \mathrm{~B}$ ).

Wheat Black mustard

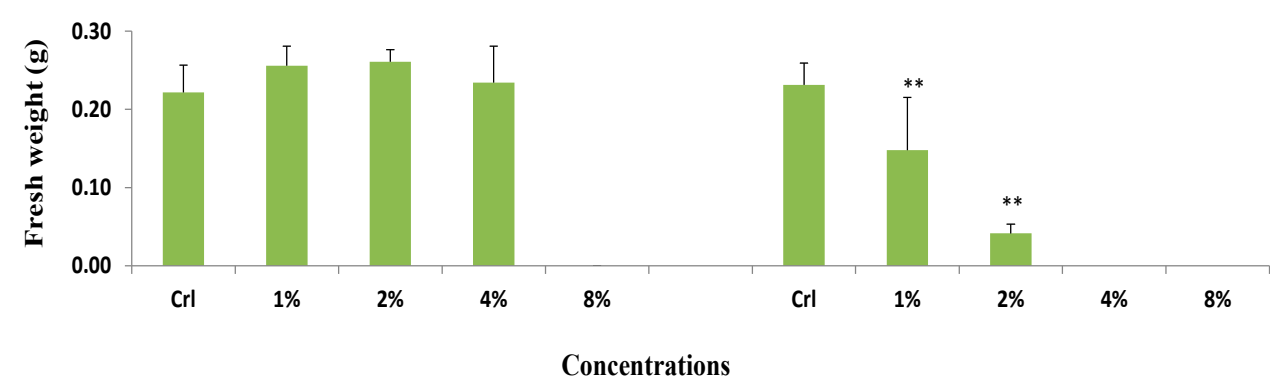

(A)

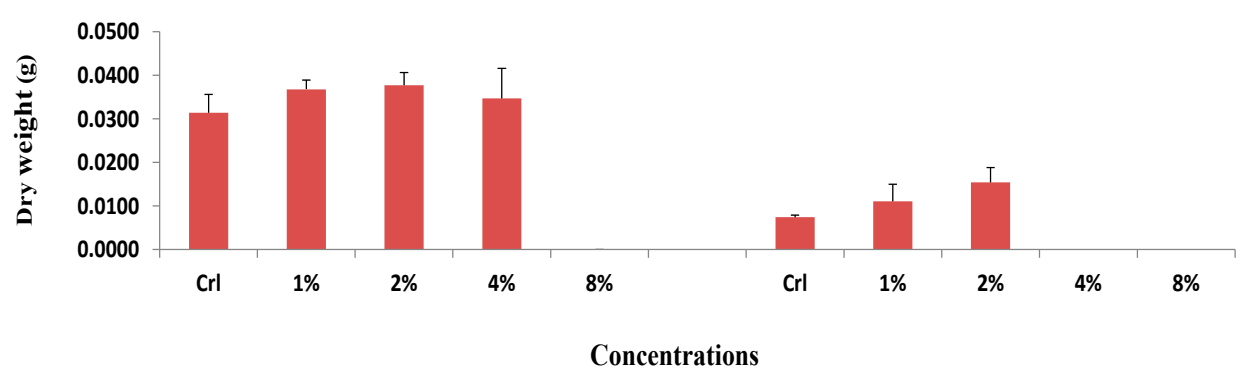

(B)

Figure 4. Effect of the aqueous extract of $H$. persicum on seedling fresh weight (A) and dry weight (B) in wheat and black mustard. ${ }^{* *}=$ highly significant. $\mathrm{Crl}=$ Control.

In our investigation, the seed germination percentage and seedling growth traits in wheat were not significantly affected by the low and moderate concentrations of the aqueous extract of H. persicum. By contrast, for black mustard weed, the moderate concentration of $H$. persicum significantly reduced seed germination, while low and moderate concentrations negatively affected seedling growth. The negative impact of $H$. persicum on seed germination and seedling growth of black mustard increased with increasing extract concentration. This trend was noticed for black mustard treated with Calotropis procera, Morettia philaeana, and Casuarina cunninghamiana extracts [26,28]. Interestingly, the response of crop plants is significantly different compared to the weed species under similar allelochemicals $[23,28]$.

The inhibitory effect of $H$. persicum on seed germination and seedling growth of black mustard may be attributed to the high content of its bioactive secondary metabolites, i.e., phenolics, flavonoids, tannins, and saponins, that have been reported to be phytotoxic and allelopathic against weeds if present at high concentrations $[18,23,26,28,29,52-56]$. The aqueous extract of Hypericum myrianthum and H. polyanthemum inhibited the seed germination percentage in Lactuca sativa $[57,58]$. The aqueous extracts of different parts of both 
Acacia nilotica and Acacia seyal have been reported to inhibit seed germination of black mustard, with the least effect on the wheat seedlings [56]. Moreover, C. cunninghamiana branchlets reduced the seed germination of black mustard, and the reduction was proportional to the concentration of the aqueous extract [28].

Although the mechanism of actions of these bioactive secondary metabolites on seed germination and seedling growth has not been completely revealed, the negative impact of donor allelochemicals on the recipient species may involve one or more mechanism(s), such as the roles of these bioactive allelochemicals in the destruction of cell membrane resulting in membrane permeability and membrane lipid peroxidation $[53,59,60]$, reduction in mitochondrial respiration $[8,60]$, cell division and hormones involved in cell division $[8,19,61]$, oxidative, antioxidant, and growth regulation systems [8], and enzymes synthesis contributing to seed germination and seedlings growth [8,62-64].

The root has been found to be the most sensitive part of black mustard seedlings that is influenced by allelochemicals [65-67], and so the root growth was greatly reduced due to the application of $H$. persicum extract. This might be due to the phytotoxic direct effect of the secondary metabolites of $H$. persicum, such as phenols, saponins, and others, affecting the permeability of membrane [53] and/or on cell division [19,28,61], or through the indirect negative effect of these bioactive metabolites on the activity of enzymes and hormones required for the mitotic division in apical root tips and seedlings' growth process [19,61].

Interestingly, at low concentrations, $H$. persicum extract stimulated wheat shoot growth while negatively affected the growth of black mustard. Low concentrations of $H$. persicum extract may contain proper concentrations of allelochemicals that played a stimulating role for wheat growth, but at the same concentration level, these compounds were inhibitory to the black mustard. This shows the species specificity of $H$. persicum allelochemicals. It was reported for many plants that when seedlings were subjected to low or moderate allelochemicals concentrations, shoot length was significantly promoted and consequently enhanced seedling weight, such as in the case of aqueous extracts of M. philaeana, A. nilotica, and $A$. seyal, which enhanced shoot length and the dry weight of wheat seedlings [26]. The increase in the weights of wheat seedlings may also be attributed to the stress counter mechanism that directed the metabolomics flux in wheat seedlings to tolerate the allelochemicals stress $[24,26]$.

\subsection{Effect of H. persicum on the Photosynthetic Pigments Content in Wheat}

Chlorophyll a, chlorophyll b, and total chlorophyll contents were significantly increased at low and moderate concentrations (1-4\%) of extract. By contrast, these parameters were significantly decreased at the highest extract concentration (8\%). Chlorophyll b is more sensitive than chlorophyll a regarding its response to the highest concentration of extract, where under the highest concentration of H. persicum, the content of chlorophyll a and $\mathrm{b}$ were reduced to $20 \%$ and $50 \%$, respectively, as compared to control (Figure $5 \mathrm{~A}-\mathrm{C}$ ). 


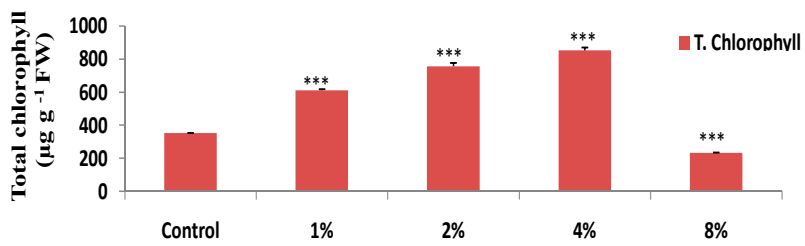

(A)

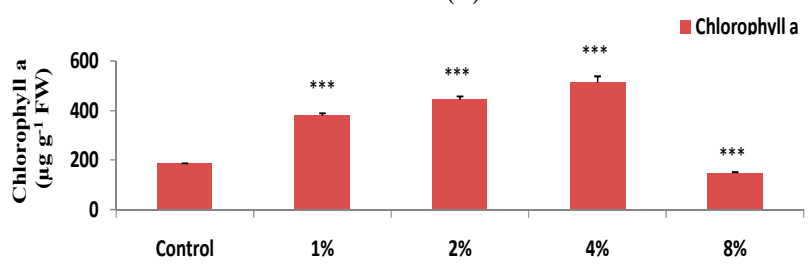

(B)

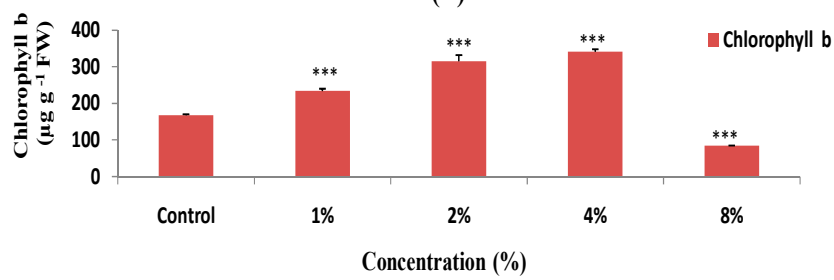

(C)

Figure 5. Effect of the aqueous extract of $H$. persicum on photosynthetic pigments in wheat. Total chlorophyll (A), chlorophyll a (B), and chlorophyll b (C). ${ }^{* * *}=$ very highly significant.

The effect of allelochemicals on the content of photosynthetic pigments varies according to the recipient species and the qualitative and quantitative content of the allelochemicals of the donor species $[19,26,28,68,69]$. In our study, the allelopathic stress of $H$. persicum significantly enhanced the level of chlorophyll a and $\mathrm{b}$ under the low and moderate content of allelochemicals, whereas the highest concentration of allelochemicals $(8 \%)$ intensively reduced the content of chlorophyll $\mathrm{a}$ and $\mathrm{b}$ in wheat seedlings. The reduction in chlorophyll $\mathrm{a}$ and $\mathrm{b}$ in wheat under allelochemicals stress is well reported in various wheat cultivars [56], including Pirsabaq, Serin, and Ata Habibin, Pakistan [68]. Furthermore, the seedlings of two different wheat varieties exposed to Helianthus annus allelochemicals also demonstrated a significant reduction in chlorophyll $a$ and $b$ [63].

\subsection{Effect of H. persicum on Carbohydrates and Proline Contents in Wheat}

Carbohydrate content was significantly reduced under the lowest concentration (1\%), whereas no significant change was recorded under other treatments (Figure 6A). On the contrary to carbohydrates, the content of proline was significantly increased in response to all treatments, with an increase with increasing extract concentration from $1 \%$ to $4 \%$ (Figure 6B). 


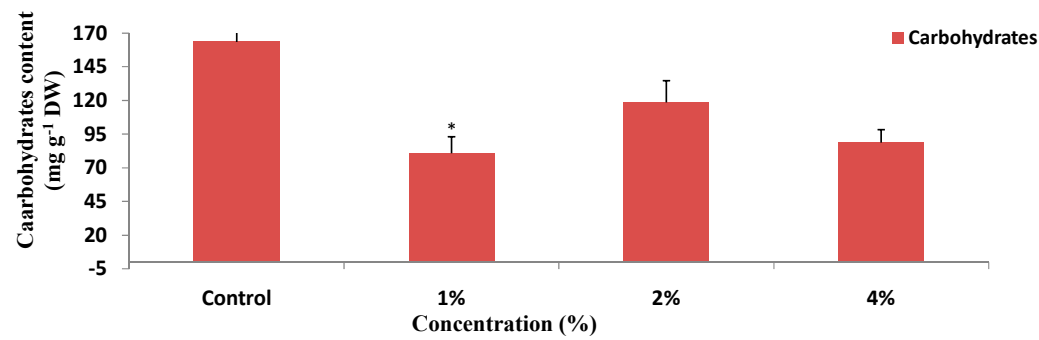

(A)

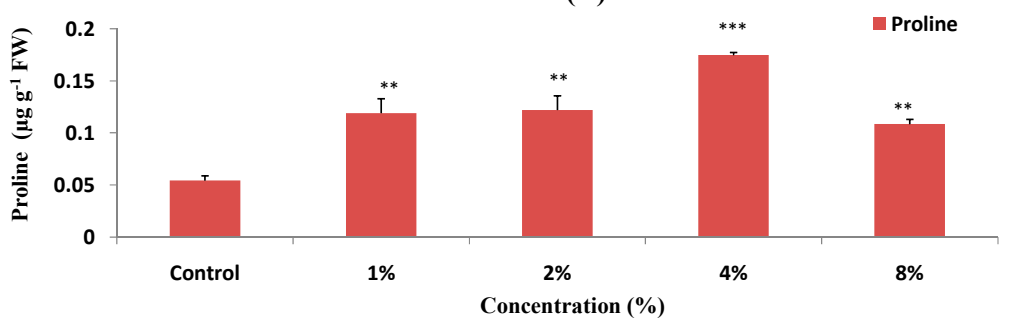

(B)

Figure 6. Effect of the aqueous extract of H. persicum on carbohydrates and proline contents in wheat. Carbohydrates (A) and proline (B). ${ }^{*}=$ significant, ${ }^{* *}=$ highly significant and ${ }^{* *}=$ very highly significant. $\mathrm{Crl}=$ Control.

The content of carbohydrates in wheat seedlings was significantly decreased only under the lowest concentration of $\mathrm{H}$. persicum, whereas no significant change occurred under higher concentrations of the extract. Citrullus colocynthis shoot aqueous extract reduced the content of carbohydrates in Vicia faba and Hordeum vulgare seedlings [70]. Artemisia monosperma and Thymus vulgare aqueous extracts decreased carbohydrates content in Pisum sativum seedlings, particularly at the highest concentrations used from the two species [70].

An increase in the content of carbohydrates was reported previously in cucmber, tomato, and wheat subjected to the aqueous extract of C. procera [24]. Furthermore, onion and garlic seed extracts reduced the content of carbohydrates in Pisum sativum, while the same concentrations of cucumber and carrot extract increased the content of carbohydrates [67].

The quantitative alteration in chlorophyll and carbohydrates in allelopathic stressed seedlings is dependent on many factors, such as plant species, variety, the sensitivity and tolerance of the recipient species, and the donor species allelochemicals (quantitative and qualitative profile), as well as the age of the seedlings [24,28,64,68-72].

Proline content was increased in wheat seedlings subjected to all concentrations of H. persicum. Proline is an osmo-regulant agent that is associated with many abiotic stresses, including drought and salinity [73-76]. Allelochemical stress may indirectly cause droughtlike stress to some plants. Moreover, increasing the proline content under allelochemical stress may enhance the stress tolerance in plants as it represents an antioxidative defense molecule [75], which is more prominent in wheat. Allelochemicals of many plants, such as those of $C$. procera, were also reported to increase the proline contents in wheat, cucumber, and tomato [24]. The increase in proline and simultaneous decrease in carbohydrates under allelochemical stress may refer to the shift of metabolomics' flux of plant from carbohydrate storage towards the osmo-regulator (proline) to cope with allelochemical stress [77], which is similar under drought stress, where NADPH and ATP are utilized for proline biosynthesis as stress counter mechanism [78]. 


\subsection{Dissecting the Effect of Allelochemical Stress on Wheat and Black Mustard Using Multivariate Data Analysis}

The effect of allelochemical stress on seed germination, growth parameters, and physiological characteristics of wheat and on seed germination and seedling growth of black mustard seedlings was studied using principal component analysis (PCA) of multivariate data analysis. As shown in Figure 7, the PCA of wheat under allelochemical stress revealed two distinct groups, one for control plants together with plants that were subjected to low and moderate concentrations of $H$. persicum allelochemicals (concentrations $1-4 \%$ ). In this group, there was no significant difference between control and low and moderate levels of $H$. persicum extract regarding the growth traits and carbohydrates content, whereas a significant difference was observed in the case of photosynthetic pigments and proline content between control seedlings and those that were treated with $1-4 \%$ aqueous extract of $H$. persicum. The second group was for seedlings that were subjected to the highest level of H. persicum ( $8 \%$ ) (Figure 7), which was characterized by very low values of growth parameters, percentage of seed germination, photosynthetic pigments (chlorophyll $\mathrm{a}, \mathrm{b}$, and total chlorophyll), and carbohydrates (Figure 7). In the case of black mustard, PCA represented discrimination of seedlings into two distinct groups, one for the control plants characterized by a high percentage of germination and high seedling growth parameters, whereas the other group included the seedlings subjected to the aqueous extract of $H$. persicum (2-8\%) characterized by a low percentage of germination and low seedling growth criteria, such as shoot and root length, fresh and dry weights (Figure 8). When data of seed germination and seedling growth of both wheat and black mustard under allelochemical stress were processed in the same score biplot (Figure 9), two distinct groups were observed, where one of these, i.e., positive PC1, included control seedlings for both wheat and black mustard and wheat seedlings subjected to low and moderate levels of $H$. persicum allelochemicals $(1-4 \%)$. This group was characterized with the highest percentage of seed germination and the greatest growth parameters values. The second group, i.e., negative PC1, included black mustard seedlings that were subjected to $2-8 \%$ concentrations of $H$. persicum extract in addition to wheat seedlings that were subjected to the highest level of H. persicum allelochemicals $(8 \%)$. This group was characterized by the lowest seed germination percentage and the lowest growth parameters (Figure 9). Black mustard plants that were subjected to $1 \%$ of $H$. persicum occupied an intermediate position between the two groups (Figure 9). This confirms that the black mustard seed germination and seedling growth were dramatically influenced by most levels $(2-8 \%)$ of the applied H. persicum allelochemicals, whereas wheat seed germination and seedling growth parameters were only influenced by the highest level $(8 \%)$ of $H$. persicum allelochemicals.

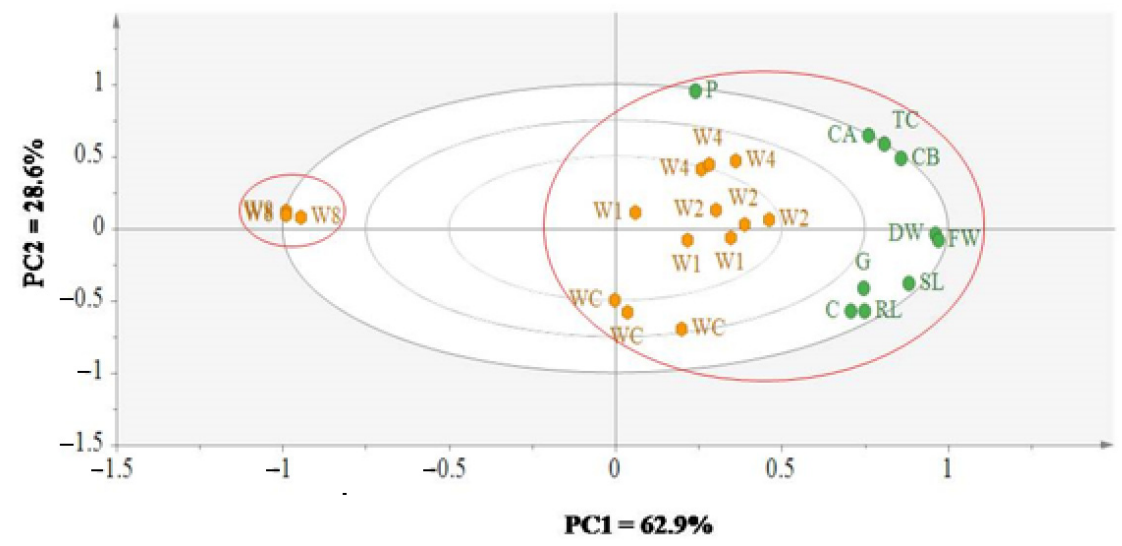

Figure 7. Effect of various concentrations of $H$. persicum aqueous extract on seed germination, seedling growth, and biochemical features in wheat. WC $=$ Wheat control; $\mathrm{W} 1=1 \%$ concentration; $\mathrm{W} 2=2 \%$ concentration; $\mathrm{W} 4=4 \%$ concentration; $\mathrm{W} 8=8 \%$ concentration; $\mathrm{TC}=$ Total chlorophyll; $\mathrm{CA}=$ Chlorophyll a; $\mathrm{CB}=$ chlorophyll b; $\mathrm{G}=$ Germination percentage; $\mathrm{DW}=$ Dry weight; FW = Fresh weight; $\mathrm{SL}=$ Shoot length; $\mathrm{RL}=$ Root length $P=$ Proline $; \mathrm{C}=$ Carbohydrates . 


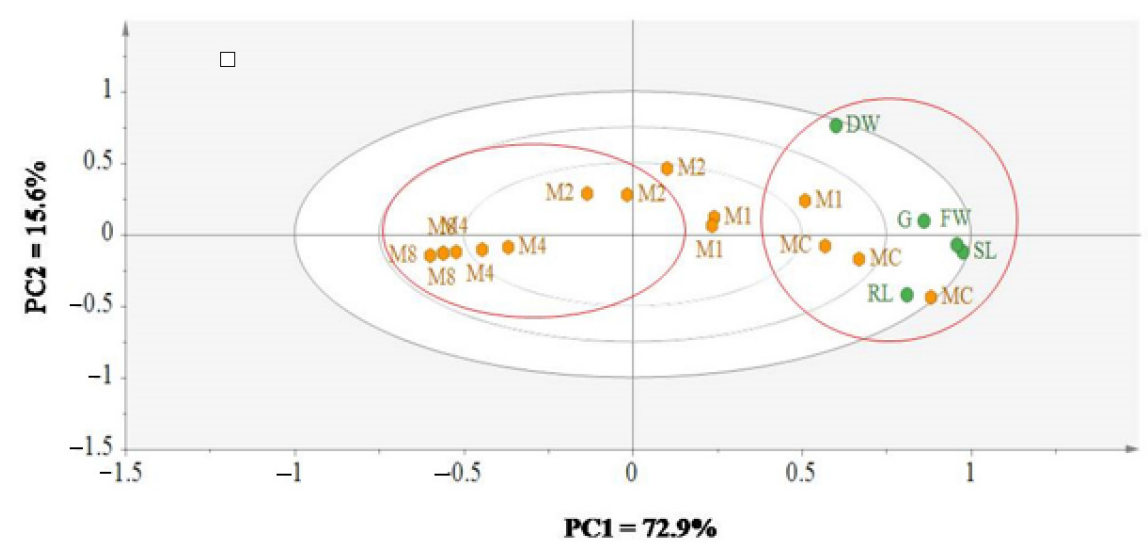

Figure 8. Effect of various concentrations of $H$. persicum aqueous extract on seed germination and seedling growth in black mustard. $M C=$ Mustard control; $M 1=1 \%$ concentration; $\mathrm{M} 2=2 \%$ concentration; $\mathrm{M} 4=4 \%$ concentration; $\mathrm{M} 8=8 \%$ concentration; $\mathrm{G}=$ Germination percentage; DW = Dry weight; FW = Fresh weight; $\mathrm{SL}=$ Shoot length, and RL = Root length.

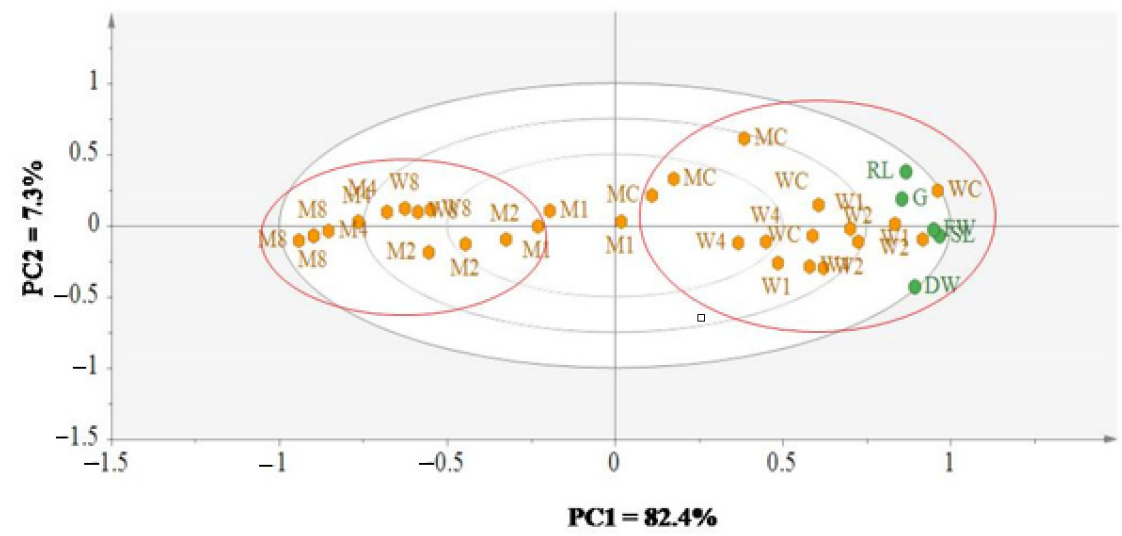

Figure 9. Effect of various concentrations of $H$. persicum aqueous extract on seed germination and seedling growth in wheat and black mustard. WC $=$ wheat control; $\mathrm{MC}=$ Mustard control; $\mathrm{W} 1=1 \%$ concentration on wheat; $\mathrm{W} 2=2 \%$ concentration on wheat; $\mathrm{W} 4=4 \%$ concentration on wheat; $\mathrm{W} 8=8 \%$ concentration on wheat; $\mathrm{M} 1=1 \%$ concentration; $\mathrm{M} 2=2 \%$ concentration; M4 $=4 \%$ concentration; M8 $=8 \%$ concentration on black mustard; $\mathrm{G}=$ Germination percentage; DW = Dry weight; FW = Fresh weight; $\mathrm{SL}=$ Shoot length, and RL = Root length.

Multivariate data analysis is used to dissect the influence of environmental stresses on plant growth and development. In a simple biplot, PCA reveals the effect of these stresses on growth parameters and biochemical changes in the recipient plant. PCA was efficiently used to dissect the effect of different levels of salinity stress on growth criteria and physiological characteristics in tomato [40]. The effect of allelochemicals' stress on the growth of tomato and cucumber was also evaluated using PCA and multivariate data analysis [28].

\subsection{Phytochemical Analysis and Antioxidant Activity of H. persicum}

Shoots of $H$. perscicum are characterized by high amounts of polyphenols, including total phenolics, flavonoids, flavonols, tannins, and anthocyanins, and also saponin (Table 1). The antioxidant activity of the methanol extract of $H$. persicum was evaluated in terms of DPPH radical scavenging activity as a percentage of inhibition. DPPH was increased with increasing the concentration used (Figure 10). $\mathrm{IC}_{50}$ of the methanol extract of H. persicum was $88.7 \mu \mathrm{g} \mathrm{mL}^{-1}$ and that of ascorbic acid was $6.87 \mu \mathrm{g} \mathrm{mL}^{-1}$ (Figure 10A,B). This reflects the strong antioxidant activity of H. persicum. 
Table 1. Phytochemical analysis of $H$. persicum shoots.

\begin{tabular}{|c|c|}
\hline Secondary Metabolites & Concentration \\
\hline Total phenolics (TP) $\mathrm{mg} \mathrm{GAE} \mathrm{g}^{-1}$ extract & $46.02 \pm 0.21$ \\
\hline Total flavonoids (TF) $\mathrm{mg} \mathrm{QE} \mathrm{g}^{-1}$ extract & $37.05 \pm 0.81$ \\
\hline Total flavonols mg QE g ${ }^{-1}$ extract & $9.3 \pm 0.68$ \\
\hline Total anthocyanins $\mu$ mole $\mathrm{g}^{-1}$ extract & $0.57 \pm 0.02$ \\
\hline Total condensed tannins $\mathrm{mg} \mathrm{CE} \mathrm{g}^{-1}$ extract & $59.73 \pm 1.28$ \\
\hline Total saponins $\mathrm{mg} \mathrm{SE}^{-1}$ extract & $143.3 \pm 1.79$ \\
\hline
\end{tabular}

$\mathrm{GAE}=$ gallic acid equivalent, $\mathrm{QE}=$ quercetin equivalent, $\mathrm{CE}=$ catechols equivalent and $\mathrm{SE}=$ saponins equivalent .

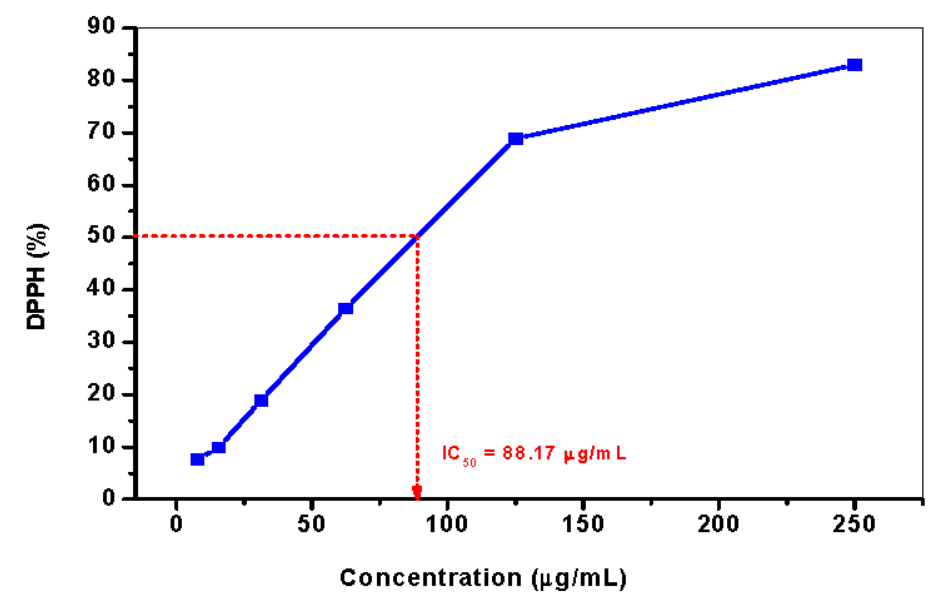

(A)

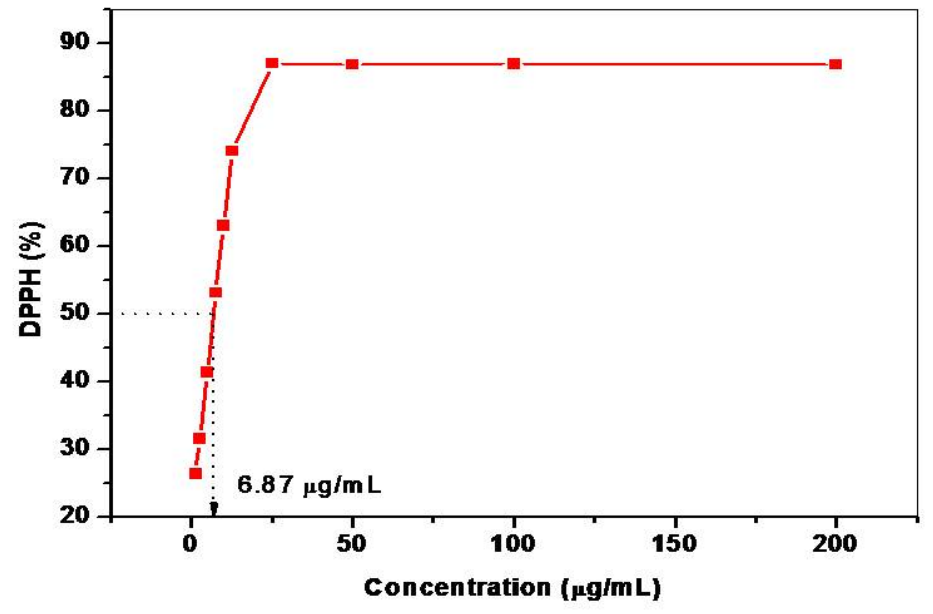

(B)

Figure 10. 2,2-Diphenyl-1-picryl-hydrazyl (DPPH) radical scavenging activity and $\mathrm{IC}_{50}$ of the methanol extract of $H$. persicum (A) and ascorbic acid (B).

The high content of bioactive secondary metabolites in H. persicum, such as polyphenols (phenolics, flavonoids, flavonols, anthocyanins, and tannins) in addition to saponins, was not only reflected in the allelopathic potentiality against the weed species, black mustard but also in its antioxidant activity showed by the higher DPPH radical scavenging activity. Different Haloxylon species were profiled for their chemical constituents and their antioxidant activity. H. salicornicum showed high content of alkaloids, saponins, tannins, steroids, flavonoids, and cardiac glycosides. The methanol extracts showed strong DPPH radical scavenging activity with higher $\mathrm{IC}_{50}$ than that reported in our study $\left(112.56 \mu \mathrm{g} \mathrm{mL}^{-1}\right)$ [79]. The high antioxidant activity of $H$. persicum and low $\mathrm{IC}_{50}$ may be 
attributed to the high content of bioactive secondary metabolites profiled, which were reported as antioxidant agents [80-82].

\section{Conclusions}

One of the positive effects of allelopathy is the use of selected plants to control the growth of weed species associated with economic cultivated crops. Low and moderate concentrations of $H$. persicum extract with its high amounts of polyphenols and saponins mostly inhibited seed germination and seedling growth of black mustard without any negative impact on wheat seed germination and seedling growth. Moreover, the photosynthetic pigment contents of wheat seedlings was enhanced after the application of low and moderate concentrations of H. persicum. Under most of the applied extract concentrations of $H$. persicum, the carbohydrates content was not significantly changed, whereas simultaneously, an increase in proline content under all concentrations was observed. It is suggested that $H$. persicum could be used to control the growth and development of black mustard weed species in wheat, and field trials are recommended. Moreover, due to its high antioxidant activity, $H$. persicum should be intensively studied to purify and isolate some antioxidant agents for potential industrial applications.

Author Contributions: Conceptualization and formal analysis, I.B.A.-F. and N.H.G.; methodology and investigation, M.S.M. and Y.A.-E.; data curation, M.J., M.S.M., and A.A.H.A.L.; software and visualization, I.B.A.-F. and M.J.; validation, N.H.G. and A.A.H.A.L.; writing-original draft preparation, I.B.A.-F. and N.H.G.; writing—review \& editing, I.B.A.-F., N.H.G., M.J., and A.A.H.A.L. All authors have read and agreed to the published version of the manuscript.

Funding: This research was funded by Taif University Researchers Supporting Project number (TURSP-2020/72), Taif University, Taif, Saudi Arabia.

Institutional Review Board Statement: Not applicable.

Informed Consent Statement: Not applicable.

Data Availability Statement: The data presented in this study are available on request from the corresponding author.

Conflicts of Interest: The authors declare no conflict of interest.

\section{References}

1. Patterson, D.T. Allelopathy. In Research Methods in Weed Science, 3rd ed.; Camper, N.D., Ed.; Southern Weed Science Society: Champaign, IL, USA, 1986; pp. 111-134.

2. Zeng, R.S. Allelopathy in Chinese ancient and modern agriculture. In Allelopathy in Suitable Agriculture and Forestry; Zeng, R.S., Mallik, A.Z., Luo, S.M., Eds.; Springer: New York, NY, USA, 2008; pp. 39-59.

3. Korres, N.E.; Norsworthy, J.K.; Tehranchian, P.; Gitsopoulos, T.K.; Loka, D.A.; Oosterhuis, D.M.; Gealy, D.R.; Moss, R.S.; Burgos, N.R.; Miller, M.R.; et al. Cultivars to face climate change effects on crops and weeds: A review. Agron. Sustain. Dev. 2016, 36, 12. [CrossRef]

4. Zohaib, A.; Tabassum, T.; Anjum, S.A.; Abbas, T.; Nazir, U. Allelopathic effect of some associated weeds of wheat on germinability and biomass production of wheat seedlings. Plant Dan. 2017, 35, 1-12. [CrossRef]

5. Han, X.; Cheng, Z.; Meng, H.; Yang, X.; Ahmad, I. Allelopathic effect of decomposed garlic (Allium sativum L.) stalk on lettuce (L. sativa var. crispa L.). Pak. J. Bot. 2013, 45, 225-233.

6. Jabran, K.; Mahajan, G.; Sardana, V.; Chauhan, B.S. Allelopathy for weed control in agricultural systems. Crop Prot. 2015, 72, 57-65. [CrossRef]

7. Kohli, R.K.; Batish, D.R.; Singh, H.P. Eucalyptus oils for the control of Parthenium (Parthenium hysterophorus L.). Crop Prot. 1998, 17, 119-122. [CrossRef]

8. Cheng, F.; Cheng, Z. Research progress on the use of plant allelopathy in agriculture and the physiological and ecological mechanisms of allelopathy.Front. Plant Sci. 2015, 6, 1020. [CrossRef]

9. Sarfraz, M.; Ahmad, M.; Noor, W.S.A.W.M.; Ashraf, M.A. Pollution Prevention, Best Management Practices, and Conservation. In Organic Farming: A Promising Way of Food Production; InTech: London, UK, 2016. [CrossRef]

10. Bhowmik, P.C.; Inderjit. Challenges and opportunities in implementing allelopathy for natural weed management. Crop Prot. 2003, 22, 661-671. [CrossRef]

11. Rice, E.L. Biological Control of Weeds and Plant Diseases: Advances in Applied Allelopathy; Oklahoma University Press: Norman, OK, USA, 1995. Available online: https:/ /lib.ugent.be/catalog/rug01:000351620 (accessed on 1 December 2020). 
12. Torres, A.; Oliva, R.M.; Castellano, D.; Cross, P. First World Congress on Allelopathy-A Science of the Future, Cadiz, Spain, 16-20 September 1996; University of Cadiz: Cadiz, Spain, 1996.

13. Kruse, M.; Strandberg, M.; Strandberg, B. Ecological Effects of Allelopathic Plants-A Review; NERI Technical Report; National Environmental Research Institute: Silkeborg, Denmark, 2000.

14. Oleszek, W.; Jurzysta, M. The allelopathic potential of alfalfa root medicagenic acid glycosides and their fate in soil environments. Plant Soil 1987, 98, 67-80. [CrossRef]

15. Edewor, T.I.; Ibikunle, G.J.; Usman, L.A. Phytotoxic and antimicrobial screening of saponin isolated from ethanolic leaf extract of Xylopia aethipioca. Sci. Focus 2009, 14, 507-512.

16. Bialy, Z.; Oleszek, W.; Lewis, J.; Fenwick, G.R. Allelopathic potential of glucosinolates (mustard oil glycosides) and their degradation products against wheat. Plant Soil 1990, 129, 277-281. [CrossRef]

17. Abdel-Farid, I.B.; Sheded, M.G.; Mohamed, E.A. Metabolomic profiling and antioxidant activity of some Acacia species. Saudi J. Biol. Sci. 2014, 21, 400-408. [CrossRef] [PubMed]

18. Li, Z.R.; Amist, N.; Bai, L.Y. Allelopathy in sustainable weeds management. Allelopathy J. 2019, 48, 109-138. [CrossRef]

19. Al-Wakeel, S.A.; Gabr, M.A.; Hamid, A.A.; Abu-El-Soud, W.M. Allelopathic effects of Acacia nilotica leaf residue on Pisum sativum L. J. Allelopathy 2007, 19, 411-421.

20. Kobayashi, K. Factors affecting phytotoxic activity of allelochemicals in soil. Weed Biol. Manag. 2004, 4, 1-7. [CrossRef]

21. Haig, T. Allelochemicals in Plants. In Allelopathy in Sustainable Agriculture and Forestry; Zeng, R.S., Mallik, A.U., Luo, S.M., Eds.; Springer: New York, NY, USA, 2008; pp. 63-104. [CrossRef]

22. Moameri, M.; Khalaki, M.A.; Tavili, A. Effects of Haloxylon aphyllum (Minkw.) lljin extract on seeds germination and seedlings growth of Agropyron elongatum (Host.) and Agropyron desertorum (Fisch.). Res. J. Seed Sci. 2011, 4, 40-50. [CrossRef]

23. Gomaa, N.H.; Hassan, M.O.; Fahmy, G.M.; González, L.; Hammouda, O.; Atteya, A.M. Allelopathic effects of Sonchus oleraceus L. on the germination and seedling growth of crop and weed species. Acta Bot. Braz. 2014, 28, 408-416. [CrossRef]

24. El-Khatib, A.A.; Barakat, N.A.; Nazeir, H. Growth and physiological response of some cultivated species under allelopathic stress of Calotropis procera (Aiton) W.T. Appl. Sci. Rep. 2016, 14, 237-246. [CrossRef]

25. Gomaa, N.H.; AbdElgawad, H.R. Phytotoxic effects of Echinochloa colona (L.) Link. (Poaceae) extracts on the germination and seedling growth of weeds. Span. J. Agric. Res. 2012, 10, 492-501. [CrossRef]

26. Abdel-Farid, I.B.; El-Sayed, M.A.; Mohamed, E.A. Allelopathic potential of Calotropis procera and Morettia philaeana. Int. J. Agric. Biol. 2013, 15, 120-134.

27. Hozayn, M.; El-Shahawy, T.A.; Abd El-Monem, A.A.; El-Saady, A.A.; Darwish, M.A. Allelopathic effect of Casuarina equisetifolia L. on wheat, associated weeds and nutrient content in the soil. Afr. J. Agric. Res. 2015, 10, 1675-1683. [CrossRef]

28. Sheded, M.; Jahangir, M.; Marghany, M.; Abdel-Farid, I.B. Effect of Casuarina allelochemicals on growth of cultivated and weed plants. J. Bio-Mol. Sci. 2017, 5, 1-14.

29. Ghimire, B.K.; Ghimire, B.; Yu, C.Y.; Chung, I.M. Allelopathic and autotoxic effects of Medicago sativa-Derived allelochemicals. Plants 2019, 8, 233. [CrossRef]

30. Kapoor, D.; Rinzim; Tiwari, A.; Sehgal, A.; Landi, M.; Brestic, M.; Sharma, A. Exploiting the allelopathic potential of aqueous leaf extracts of Artemisia absinthium and Psidium guajava against Parthenium hysterophorus, a widespread weed in India. Plants 2019, 8, 552. [CrossRef] [PubMed]

31. Yang, L.; Wen, K.S.; Ruan, X.; Zhao, Y.X.; Wei, F.; Wang, Q. Response of plant secondary metabolites to environmental factors. Molecules 2018, 23, 762. [CrossRef] [PubMed]

32. Isah, T. Stress and defense responses in plant secondary metabolites production. Biol. Res. 2019, 52, 39. [CrossRef]

33. Alghanem, S.M. Ecological and botanical diversity in Haloxylon persicum community at Al-Qassim Region in Kingdom of Saudi Arabia. Am. J. Environ. Prot. 2018, 6, 43-49. [CrossRef]

34. Song, J.I.E.; Feng, G.U.; Tian, C.; Zhang, F. Strategies for adaptation of Suaeda physophora, Haloxylon ammodendron and Haloxylon persicum to a saline environment during seed-germination stage. Ann. Bot. 2005, 96, 399-405. [CrossRef]

35. Al-Khalifah, N.S.; Shanavaskhan, A.E. On the distribution, status and phenology of Ghada (Haloxylon persicum Bunge) in the Arabian peninsula. Trop. Ecol. 2007, 48, 51-60.

36. Xu, G.; Yu, D.; Xie, J.; Tang, L.; Li, Y. What makes Haloxylon persicum grow on sand dunes while H. ammodendron grows on interdune lowlands: A proof from reciprocal transplant experiments. J. Arid Land 2014, 6, 581-591. [CrossRef]

37. El-Khatib, A.A.; Abd-Elaah, G.A. Allelopathic potential of Zilla spinosa on growth of associate flowering plants and some rhizosphere fungi. Biol. Plant. 1998, 41, 461-467. [CrossRef]

38. Grange, S.L.; Leskovar, D.I.; Pike, L.M.; Cobb, B.G. Excess moisture and seed coat nicking influence germination of triploid watermelon. HortScience 2000, 35, 1355-1356. [CrossRef]

39. Zucconi, F.; Forte, M.; Monaco, A.D.E.; De Bertoldi, M. Biological evaluation of compost maturity. BioCycleb 1981, $22,27-29$.

40. Abdel-Farid, I.B.; Marghany, M.R.; Rowezek, M.M.; Sheded, M.G. Effect of salinity stress on growth and metabolomic profiling of Cucumis sativus and Solanum lycopersicum. Plants 2020, 9, 1626. [CrossRef] [PubMed]

41. Morris, D.L. Quantitative determination of carbohydrates with Dreywood'santhrone reagent. Science 1948, 107, $254-255$. [CrossRef] [PubMed]

42. Bates, L.S.; Waldren, R.P.; Teare, I.D. Rapid determination of free proline for water-stress studies. Plant Soil 1973, 39, $205-207$. [CrossRef] 
43. Dere, S.; Güneş, T.; Sivaci, R. Spectrophotometric determination of chlorophyll A, B and total carotenoid contents of some algae species using different solvents. Tur. J. Bot. 1998, 22, 13-17.

44. Singleton, V.L.; Orthofer, R.; Lamuela-Raventos, R.M. Analysis of total phenols and other oxidation substrates and antioxidants by means of Folin-ciocalteau reagent. Methods Enzymol. 1999, 299, 152-178. [CrossRef]

45. Zhishen, J.; Mengcheng, T.; Jianming, W. The determination of flavonoid contents in mulberry and their scavenging effects on superoxide radicals. Food Chem. 1999, 64, 555-559. [CrossRef]

46. Kumaran, A.; Karunakaran, R.J. In vitro antioxidant activities of methanol extracts of five Phyllanthus species from India. LWT Food Sci. Technol. 2007, 40, 344-352. [CrossRef]

47. Padmavati, M.; Sakthivel, N.; Thara, K.V.; Reddy, A.R. Differential sensitivity of rice pathogens to growth inhibition by flavonoids. Phytochemistry 1997, 46, 499-502. [CrossRef]

48. Julkunen-Titto, R. Phenolics constituents in the leaves of northern Willows. Methods for the analysis of certain phenolics. J. Agric. Food Chem. 1985, 33, 213-217. [CrossRef]

49. Ebrahimzadeh, H.; Niknam, V.A. revised spectrophotometric method for determination of triterpenoid saponins. Indian Drugs 1998, 35, 379-381.

50. Blois, M.S. Antioxidant determinations by the use of a stable free radical. Nature 1958, 181, 1199-1200. [CrossRef]

51. Wang, J.; Mazza, G. : Effect of anthocyanins and other phenolic compounds on the production of tumor necrosis factor alpha in LPS/IFN-gamma- activated RAW 264.7 macrophages. J. Agric. Food. Chem. 2002, 50, 4183-4189. [CrossRef]

52. Hegazy, A.K.; Fadl-Allah, E.M. Inhibition of seed germination and seedling growth by Cleome droserifolia and allelopathic effect on rhizosphere fungi in Egypt. J. Arid. Environ. 1995, 29, 3-11. [CrossRef]

53. Reigosa, M.J.; Gonzalez, L.; Sanches-Moreiras, A.; Duran, B.; Puime, D.; Fernandez, D.A.; Bolano, J.C. Comparison of physiological effects of allelochemicals and commercial herbicides. Allelopathy J. 2001, 8, 211-220.

54. Sisodia, S.; Siddiqui, M.B. Allelopathic effect by aqueous extracts of different parts of Croton bonplandianum Baill. on some crop and weed plants. J. Agric. Exten. Rural Dev. 2010, 2, 22-28.

55. Tanveer, A.; Jabbar, M.K.; Kahliq, A.; Matloob, A.; Abbas, R.; Javaid, M.M. Allelopathic effects of aqueous and organic fractions of Euphorbia dracunculoides Lam. on germination and seedling growth of chickpea and wheat. Chil. J. Agric. Res. 2012, 72, 495-501. [CrossRef]

56. Mohamed, E.A. Metabolomic Profiling, Allelopathic Potential, Antioxidant Capacity and Biological Activity of Some Acacia Species. Master's Thesis, Aswan University, Aswan, Egypt, 2015.

57. Fritz, D.; Bernardi, A.P.; Haas, J.S.; Ascoli, B.M.; Bordignon, S.A.D.L.; Von Poser, G. Germination and growth inhibitory effects of Hypericum myrianthum and H. polyanthemum extracts on Lactuca sativa L. Rev. Bras. Farmacog. 2007, 17, 44-48. [CrossRef]

58. Hussain, M.I.; El-Sheikh, M.A.; Reigosa, M.J. Allelopathic potential of aqueous extract from Acacia melanoxylon R. Br. on Lactuca sativa. Plants 2020, 9, 1228. [CrossRef] [PubMed]

59. Politycka, B. Phenolics and the activities of phenylalanine ammonia-lyase, phenol- $\beta$-glucosyltransferase and $\beta$-glucosidase in cucumber roots as affected by phenolic allelochemicals. Acta Physiol. Plant. 1998, 20, 405-410. [CrossRef]

60. Omezzine, F.; Ladhari, A.; Haouala, R. Physiological and biochemical mechanisms of allelochemicals in aqueous extracts of diploid and mixoploid Trigonella foenum-graecum L. S. Afr. J. Bot. 2014, 93, 167-178. [CrossRef]

61. Callaway, R.M.; Aschehoug, E.T. Invasive plant versus their new and old neighbours: A mechanism for exotic invasion. Science 2000, 290, 521-523. [CrossRef] [PubMed]

62. Al-Zahrani, H.S.; Al-Robai, S.A. Allelopathic effect of Calotropis procera leaves extract on seed germination of some plants. JKAU Sci. 2007, 19, 115-126. [CrossRef]

63. Kamal, J. Impact of allelopathy of sunflower (Helianthus annuus L.) roots extract on physiology of wheat (Triticum aestivum L.). Afr. J. Biotechnol. 2011, 10, 14465-14477. [CrossRef]

64. Qasem, J.R. The allelopathic effect of three Amaranthus spp. (Pigweeds) on wheat (Triticum durum). Weed Res. 1995, 35, 41-49. [CrossRef]

65. Turk, M.A.; Lee, K.D.; Tawaha, A.M. Inhibitory effects of aqueous extracts of black mustard on germination and growth of radish. Res. J. Agric. Biol. Sci. 2005, 1, 227-231.

66. Hassan, S.M.; Ghareib, H.R. Bioactivity of Ulva lactuca L. acetone extract on germination and growth of lettuce and tomato plants. Afr. J. Biotechnol. 2009, 8, 3832-3838. [CrossRef]

67. Abou El-Ghit, H.M. Physiological allelopathic effect of aqueous extracts of cucumber, carrot, onion, and garlic seeds on germination and growth of Pea. J. Pharma. Chem. Biol. Sci. 2016, 4, 13-19.

68. Siyar, S.; Majeed, A.; Muhammad, Z.; Ali, H.; Inayat, N. Allelopathic effect of aqueous extracts of three weed species on the growth and leaf chlorophyll content of bread wheat. Acta Ecol. Sin. 2019, 39, 63-68. [CrossRef]

69. Salama, H.M.; Al Rabiah, H.K. Physiological effects of allelopathic activity of Citrullus colocynthis on Vicia faba and Hordeum vulgare. Eur. J. Biol. Res. 2015, 5, 25-35.

70. Hamad, S.; Mahgoub, A.M. Allelopathic potentials of Artemisia monosperma and Thymus vulgaris on growth and physiobiochemical characteristics of Pea seedlings. Pak. J. Biol. Sci. 2018, 21, 187. [CrossRef] [PubMed]

71. Abu-Romman, S. Differential allelopathic expression of different plant parts of Achillea biebersteinii. Acta Biol. Hung. 2016, 67, 159-168. [CrossRef] [PubMed] 
72. Ding, H.; Ali, A.; Cheng, Z. An allelopathic role for garlic root exudates in the regulation of carbohydrate metabolism in cucumber in a hydroponic co-culture system. Plants 2020, 9, 45. [CrossRef]

73. Heuer, B. Role of proline in plant response to drought and salinity. In Handbook of Plant and Crop Stress; CRC Press: Boca Raton, FL, USA, 2010; pp. 213-238. [CrossRef]

74. Hayat, S.; Hayat, Q.; Alyemeni, M.N.; Wani, A.S.; Pichtel, J.; Ahmad, A. Role of proline under changing environments: A review. Plants Signal. Behav. 2012, 7, 1456-1466. [CrossRef]

75. Kumar, B.; Tiwari, A.; Saharawat, Y.S.; McDonald, A.J. Proline content as a stress indicator to quantify conservation agriculture effect in wheat crop. Res. Crops 2015, 16, 422-431. [CrossRef]

76. Siddique, A.; Kandpal, G.; Kumar, P. Proline accumulation and its defensive role under diverse stress condition in plants: An overview. J. Pure Appl. Microbiol. 2018, 12, 1655-1659. [CrossRef]

77. Mittler, R. Abiotic stress, the field environment and stress combination. Trends Plant Sci. 2006, 11, 15-19. [CrossRef]

78. Patakas, A.; Noitsakis, B. Leaf age effects on solute accumulation in water-stressed grapevines. J. Plant Physiol 2001, 158, 63-69. [CrossRef]

79. Alshamsi, M.M.; Alnuaimi, A.K.; Alshamsi, R.M.; Senthilkumar, A.; Karthishwaran, K.; Al-Zayadneh, W.A.; Cheruth, A.J. Phytochemical analysis and antioxidant activity of Haloxylon salicarnicum, Ochradenus arabicus and Tamarix nilotica. J. Phytol. 2019, 11, 47-50. [CrossRef]

80. Korat Avni, N.; Kavathiya, Y.A.; Lakhani, N.S.; Kandoliya, U.K.; BA, G.; Golakiya, B.A. Nutritional and antioxidant components of fenugreek (Trigonella foenum-graecum L.) seedlings. J. Pharm. Phytochem. 2019, 8, 443-447.

81. Miyamae, Y.; Kurisu, M.; Han, J.; Isoda, H.; Shigemori, H. Structure-activity relationship of caffeoylquinic acids on the accelerating activity on ATP production. Chem. Pharm. Bull. 2011, 59, 502-507. [CrossRef] [PubMed]

82. Mahmoud, A.M. Influence of rutin on biochemical alterations in hyperammonemia in rats. Exp. Toxicol. Pathol. 2012, 64, 783-789. [CrossRef] [PubMed] 